\title{
7 \\ Public policy processes in Australia: Reflections from experience ${ }^{1}$
}

\author{
Meredith Edwards²
}

\section{Introduction}

I spent 14 years (1983-97) as a senior Commonwealth public servant, mostly as a policy adviser. This was a relatively narrow public service perspective, in that it did not include implementation or corporate roles, yet my experience was broad in other ways. As a public servant, I was twice employed as a ministerial consultant. I was responsible to the secretary of the department while also working to a minister and, unusually, worked from within the bureaucracy rather than on the minister's personal staff. ${ }^{3}$ Contributing to a broader view, I came to the public service from academia as a researcher with radical policy ideas, having also built up strong links with non-government organisations. I was therefore more comfortable as a 'boundary player' and being a catalyst for change than were many of my public service colleagues.

\footnotetext{
1 This chapter is a revised and extended version of a contribution commissioned for Power, parliament and politics: Essays in honour of JR Nethercote, edited by Henry Ergas and JJ Pincus (forthcoming).

2 I am grateful for insightful comments I received on an earlier draft of this paper from Russell Ayres, Alison Smith, Trish Mercer, Jonathan Pincus and Pamela Burton. I remain responsible for any errors and all views expressed.

3 From 1984, ministers were able to appoint consultants who were not under the Public Service Board. In addition, 'consultants can, with the agreement of the department head, work within the department itself as additions to the public service staff numbers' (Wilenski 1986, p. 194).
} 
I was most fortunate to work in the Hawke-Keating era of activist reform and, in that context, I was able to provide policy advice on a number of major (mainly social) policy changes-which I would call reforms in the true sense of the word ${ }^{4}$-notably:

- simplifying youth allowances

- developing a child support scheme

- introducing the Higher Education Contribution Scheme

- developing a national housing strategy

- assisting long-term unemployed people back into work.

Following the period in which I was most active as a policy adviser, there have been many significant changes in the policy environment that tend to render policy outcomes more uncertain, such as:

- global forces are more influential on domestic issues

- technology is advancing in unanticipated directions

- a 24/7 media cycle has become entrenched and magnified or distorted by social media

- tight budgets, not helped by an ageing population

- society is more networked

- power is more dispersed (including to ministerial advisers and non-government players)

- a blurring of boundaries across sectors

- growing citizen distrust in governments

- increasingly rapid and unpredictable changes in party political leaderships

- parliaments are less stable and minority governments are more common.

In addition, within public services it is now commonly argued that the capability to develop policy and to coordinate responses across government(s) has declined alongside a loss of institutional memory (see e.g. Banks 2014a, p. 14; Donaldson 2018). Not unrelated is an apparent lack of courageous political leadership (Edwards et al. 2017). Despite rhetoric to the contrary, there is much evidence of a risk-averse

4 I use reform in the way that Gary Banks (2010, pp. 4-5) does: he suggests 'reform' be used only to refer to policies that lead to change that is likely to lead to a net benefit to the community over time. 
public service environment with middle management becoming less, and not more empowered, holding back innovative policy initiatives (Behm 2015, pp. 198-200; Productivity Commission 2017). The then head of the Department of the Prime Minister and Cabinet, Martin Parkinson, called on public servants to: 'Think big. Aim high. Experiment. Be ruthless. Ask the simple questions if something is not working' (as cited in Dennett 2017). But there remains a big gap between the talk and the action.

These factors indicate a very different and more challenging policymaking environment from the 1980s and 1990s. However, most of the fundamentals of good policy process remain, and it is still true that 'good process makes not only for good policy, but ultimately for good politics too' (Banks 2013, p. 2). As such, the 'fundamental principles of good policy processes should be timeless, even if the manner of their execution must adapt to the times' (Banks 2014b, p. 43). Effective policy development still requires good analysis combined with an artful mix of process, people and politics.

The fundamentals remain constant for the three main but related roles of a policy adviser: analytical, administrative and relational. Head (2015, p. 53) describes these roles well:

- The analytical role includes examining and comparing policy options, as well as evaluating current policies and programs.

- The administrative role is about how to proceed with developing policy including coordinating across relevant agencies and paying attention to organisational processes and structures.

- The relational role involves testing how acceptable might be policy choices, consulting, negotiating and ultimately taking into account political and financial constraints.

What follows are my reflections as a policy adviser who played these roles in developing policy in the 1980s and 1990s-reflections that should resonate with policy advisers of today. They may also help inform researchers interested in the practicalities of the policy process. 


\section{Seven reflections}

Any good policy development process will follow some form of organising framework. Many have appeared in the relevant literature over the past 50 years or so. ${ }^{5}$ Despite the complexities of the real world, an attempt at a systematic approach to policy development can deliver significant benefits in addressing policy problems.

In my practice, I used a policy cycle framework that is a variant of Bridgman and Davis's so-called 'policy cycle model' (Althaus, Bridgman \& Davis 2018). This framework is reflected in my book on the policy process (Edwards 2001) and is outlined below. But there are several possible levels and modes of analysis of the policy process. What follows, therefore, goes beyond the policy cycle approach to encompass other factors important in achieving successful policy outcomes:

- placing the problem in a broader economic, social and political context

- choosing carefully appropriate organisational processes and structures

- the role of players and the value of their networks

- the role of values and, of course, politics as paramount in achieving policy outcomes.

\section{Considering the context}

A policy proposal that is tied to the government's current priorities is likely to get a better hearing than if it is not. A good starting point is the party policy platform and party ideologies, which set the boundaries as to what may and may not be possible in both the short- and longer-term. As a former federal Labor minister, Nicola Roxon, remarked: 'Neglecting to provide advice that reflects the government's platform is one of the biggest ministerial pet peeves' (as cited in Donaldson 2018). This does not require public servants to compromise on providing impartial advice, but they do need to be attuned to the government's agenda.

The economic, social and political context was highly relevant in the policy development processes around the introduction of Australia's Child Support Scheme in the 1980s. This scheme was introduced at a time

5 See, for example, Chapter 11 by Louise Gilding in this volume on the use of a blended framework with a strategic triangle as its centrepiece. 
of a large budget deficit and government was searching for new revenue sources. But it was also a time of concern about poverty among those on low incomes, particularly sole parent families. Therefore, the ministers for Social Security and Finance at the time both had a stake in a scheme that would reduce pressure on the budget as well as assist in alleviating child poverty. It was the right policy at the right time. Contrast this with the environment that faced the development of a national housing strategy in the late 1980s and early 1990s, when policies put forward to assist low income households in housing stress into rental accommodation failed, despite a comprehensive research process, because the focus of government and the public at that time was on high interest rates that inhibited people from gaining a foothold into home ownership.

Other factors may be relevant in a policy context, such as:

- timing (e.g. when an election is likely to occur)

- institutional arrangements (e.g. 'how' different agencies or levels of government relate to each other)

- the key actors to influence within relevant organisations.

And, of course, political leadership is crucial: Hawke and Keating were leaders who demonstrated political courage by making tough decisions alongside being good communicators and, above all, great persuaders. (How different the scene has been over the last decade!)

\section{Covering all policy stages}

The policy environment can be likened to a stormy sea, with the policy adviser trying to take a small boat across choppy waters (Edwards 2010a, p. 425). The effort required is great, and there can be considerable risk, but there can be successful ways to navigate a course.

In the 1980s and 1990s, complex policy issues required involvement of a diverse range of players across sectors. It was a messy policy environment and, at times, politically chaotic. In spite of this, my experience was that identifying stages in policy development as a guiding framework, if used flexibly, can assist considerably in policy advising. In other words, a systematic approach to policy development, such as the policy cycle approach, can deliver significant benefits of order and process in addressing policy problems (see e.g. Althaus, Bridgman \& Davis 2018; Banks 2010; Edwards 2004). 
Using a policy cycle framework, my book on policy development (Edwards 2001) explained how four major policies developed through each policy stage:

a. clarifying the problem (defining and articulating the issues)

b. understanding key values and other questions

c. policy analysis (collecting relevant data and information and clarifying objectives)

d. undertaking consultation

e. moving towards decisions

f. implementation

g. evaluation.

Because these policy initiatives were significant, complex, cross-departmental and involved politically sensitive issues, it was important to cover each of the policy stages. However, far from being a linear process, it was more like an improvised dance (Althaus, Bridgman \& Davis 2018, p. 31). Stages were often visited in a different order, or revisited, and there were backward as well as forward movements across stages, or even overlapping stages. The process can be iterative and adapted to circumstances. In some cases, it would have been inefficient to backtrack; in other cases, backtracking seemed to be the only way through to a solution.

Backtracking on original intent occurred when, for political reasons, the child support proposal needed to be introduced in two phases rather than all in one go. Problem identification can overlap with a policy idea when the policy idea gives momentum to the reform agenda. Similarly, overlaps can occur between policy analysis and consultation, or policy analysis and clarifying the problem. It was clear to me, however, that unless each stage is covered, major policy proposals would have less chance of emerging into reality. A good policy process is necessary, though not sufficient, in most instances, to ensure policy objectives are achieved (Althaus, Bridgman $\&$ Davis 2018, p. 52; Banks 2010, p. 63; Keating 1996, p. 63).

Some political scientists have been sceptical of the policy cycle approach. Hal Colebatch, for example, has suggested that it fails to consider the full range of policy actors involved and their relative importance in policymaking (Colebatch 2006). But consultation-tailored to the sensitivity of the issue and who is to be consulted as well as when-is, in fact, taken into account in both the Bridgman and Davis version as well as my own (see below). 
It has also been argued, for example by Everett (2003), that the policy cycle is a form of 'rationalism'. Given that policy environments are full of complexities, it is not likely that anything approaching classical rationality in the decision-making process will be observed. As Bridgman and Davis (2003, p. 100), both with public service policy experience, have remarked: 'The policy cycle is logical—each step leads to the next—but does not embody formal rationality'. They would also agree with Banks (2018) that, far from a rigid sequential approach, there will be loops and iterations and that models of 'good process' are about 'what should be rather than what is'.

Despite being controversial among political scientists, in my experience the policy cycle framework can serve as a bridge between the ideal of the process and the practice: as a valuable, if rough, guide to action in pursuing success for a policy position. It certainly was a concept familiar to fellow public servants, and sharing the same language helped us work out together where we were at and what might be the next steps (see Ayres this volume, Chapter 8).

Clarifying the problem: the policy problem needs to be identified and wellarticulated for it to be owned by the public. Only once the problem is clarified do people tend to ask: 'what can we do about it?'

In the radical child support reforms of the 1980s, it was relatively easy to articulate the problem: why should kids suffer and taxpayers foot the bill just because parents decide not to live together? By way of contrast, as mentioned above, while there was general agreement that housing affordability was an important issue, there was no agreement on which aspect needed to be addressed.

Sometimes the power of a simple idea assists the articulation of the problem and gets it on the policy agenda. For example, in developing policies to assist the long-term unemployed in the first half of the 1990s, the idea of a 'job compact' provided the necessary underpinnings for policy, and imposing some obligation on the part of the long-term unemployed helped make the policy acceptable to the public (Edwards 2001, p. 178).

The notion of a 'policy window' is relevant here: that window occurs when the acknowledgement of the problem is combined with ideas on a solution that responds to political interest (Kingdon 1995). In this way, 
the problem, policy proposal and politics all came together. Of course, the language used to communicate to and influence a broad audience about these issues also mattered.

Agenda-setting matters here too. Policy issues can emerge from within as well as outside of government. Ministers are generally better able to place policy problems on a crowded agenda. This might be at their own initiative, although often they react to external pressures.

Understanding values before putting options: too often policy development stalls because policy advisers put policy options to ministers without taking account of the values that will govern their decisions. ${ }^{6}$ This is particularly the case when the problem is complex and where there is electoral sensitivity. The trade-off between efficiency in spending and more equity in outcomes is often framed by values (Edwards 2001, p. 181). In cases where decision-makers have deeply held beliefs (e.g. on euthanasia or same sex marriage), then no number of policy options or amount of evidence to support them is likely to make a difference.

Politics ultimately determines whether a policy progresses from stage to stage and at what pace, and values link policy and politics (see e.g. Behm 2015, p. 202; Botterill \& Fenna 2019). It may be a frustrating realisation that politicians might be driven more by values and emotion than 'rational' analysis of the evidence before them (Cairney \& Kwiatkowski 2017; French 2012). However, as Bromwell (2017, pp. 95-6) has remarked:

Relying on evidence and empirical analysis alone is like trying to sit on a one-legged stool-it is neither stable nor comfortable for any length of time. Effective policy advisors therefore have to engage not only with relevant data and empirical analysis, but also with emotions and social psychology, and with values and moral argument.

Public servants, therefore, are not in a good position to weigh value-based criteria. This means the policy process can be assisted by ministers giving some direction on values, such as through a set of guiding principles. A statement of principles from ministers can inform the criteria by which options are assessed.

6 For example, in the case of the reform of youth allowances in the 1980s, in the absence of such ministerial guidance, at one stage, the relevant interdepartmental committee put before ministers 16 options also referring to numerous other options that could be considered (see Edwards 2001, p. 29). 
My experience was that, where it was possible, confronting ministers early with key issues before presenting them with policy options helped them to clarify their objectives and speeded up the policy process. The issues stage could be made easier if the process started with possible areas on which ministers could agree and then moved onto harder decisions from which principles were derived, and that took into account political values. This is often a point in the process that is missed in traditional textbooks on the policy process. In the case of child support, whether to use an administrative or a court-based system needed to be argued and decided before dealing with the issue of whether to use a formula and, in turn, that issue was to be decided before the critical issue of what government agency should assess, collect and enforce payments (Edwards 2001, p. 72).

The policy analysis phase is where policy advisers can really show their expertise. Relevant data and research are analysed and options are assessed for likely consequences, based on an understanding of the decisionmaker's value framework and on key criteria, such as efficiency, equity and administrative feasibility. ${ }^{7}$ This is also the stage at which key playersinternal to government as well as external stakeholders-can be expected to participate closely, and where their differences are likely to emerge.

It is unrealistic to expect pure 'evidence-based policy' when policy and politics mix. A purist approach is flawed if it does not take into account people and their values or beliefs, or the politics, including where power lies. However, evidence-influenced policy can lead to both good policy and good politics (Head 2015). When the environment is receptive, evidence can be powerful both in clarifying a problem and in moving towards a solution.

Once ministers have decided what they want to do-as a consequence of their political values and/or pressure from their electors or party supporters - they will seek evidence to support their decision so that they can justify the policy in public (see e.g. Strangio, 't Hart \& Walter 2017, pp. 227-8). Often what is sought, therefore, is more 'policy-influenced evidence' or 'values-influenced evidence' rather than evidence-influenced policy. This challenges public servants who want to stay clear of values and politics in selecting evidence.

7 For example, see criteria used for Child Support and HECS in Edwards (2001, pp. 75-6, $115-16,118)$. 
Apart from the need to tailor evidence to the nature of the policy issue, I found different forms of evidence were needed at different stages of the policy cycle. ${ }^{8}$ Evidence about better practice, especially overseas comparisons, I found to be of great benefit in developing policies. There is substantial value in policy transfer from other countries, if ideas are adapted appropriately to local circumstances.

It is also important to 'curate' the evidence: to decide who should get the evidence and why, from whom it should come and why, as well as deciding what the decision-makers need and when, and the best ways to communicate it. This is particularly challenging today as the public appears more selective about what evidence to trust in a 'post-truth' world.

In the consultation phase, participation by stakeholders and, more broadly, citizens who are potentially affected by a possible decision, will vary depending on the nature of the issue, its complexity and sensitivity. Processes could be formal or informal, continuous or episodic. Who to consult, why, when in the policy process and how, are critical process issues (see Edwards et al. 2012, pp. 53-172). Good judgement is needed. Today, engaging stakeholders, if not co-designing with them, is recognised as more important; yet, at the same time, there appears to be a disjuncture between that recognition and reality (see e.g. Beauchamp 2016, p. 90; Burgess 2017).

Moving to policy decisions: ultimately, following refinement of original proposals, the pivotal stage occurs and policy decisions emerge in what can be a highly political context. This is where the political, policy and administrative impacts of a proposal are weighed and Cabinet consideration brings all perspectives together and 'arguments translate to a decision' (see Althaus, Bridgman \& Davis 2018, p. 169; Shergold 2015, pp. 26-30).

In all my major policy experience, implementation of Cabinet decisions was the most neglected and poorly performed policy stage. Too often, ministers announced their decisions but then lost interest as they refocused on new issues on the agenda. There are many factors that can derail policy intent, including lack of clarity around interpretation of the decision as well as respective responsibilities in the implementation process, insufficient resources allocated, insufficient attention to coordination and

8 See Working Nation example in Edwards (2010b, p. 59). 
collaboration across agencies, or a shortage of time (Edwards et al. 2012, pp. 223, 230). Despite recent focus on policy implementation, there often still appears to be a disconnect between policy aims and delivery reality.

Evaluation is the final stage in policy development in which questions of effectiveness, efficiency and continued appropriateness of objectives are assessed. Ideally it is also a stage of policy learning. A good evaluation process, as occurred in the early 1990s on long-term unemployment issues, is incorporated into the policy process before the decision stage. Evaluation needs to be timely, involve a range of people who hold a stake in the policy or program, and ensure a wide dissemination of results (Edwards 2010a, p. 421; Keating 2017, p. 2).

Evaluation can be highly political. For example, evaluation documents can be changed as they proceed from technical experts and ultimately on to the minister. In addition, those best able to assess the impact of a change, such as frontline workers, are not necessarily involved.

A welcome recent sign is the greater acknowledgement of the need to experiment with new approaches and 'learning from failure' alongside the monitoring of outcomes (Althaus, Bridgman \& Davis 2018, p. 14; Shergold 2015, pp. 63-82; Productivity Commission 2017, p. 203).

\section{Attending to organisational structures and processes}

A framework of stages in developing policy is only part of the story if desired policy outcomes are to have a chance to succeed. A common thread in good policy processes (often not given due attention in the theory of policymaking) is careful consideration of the organisational structures and processes within which policy work occurs.

A successful policy adviser will give attention to both strategy and tactics, not just addressing the important or high level ends as well as means, but also tactics to deal with more immediate matters and to manage daily processes (see Behm 2015, pp. 197-8). In fact, the single most important lesson I learnt from my time as a public servant, as keen and impatient as I was to get desired outcomes, was the critical role of processes and structures if desired outcomes were to have any chance of success. 
Ministers can tactically bypass interdepartmental committees and use other less conventional or more innovative mechanisms such as carefully selected task forces that might include not only public servants, but also ministerial advisers and or external experts, or taskforces of relevant ministers (see e.g. Edwards 2001, p. 185).

Some of the key questions I found that a policy adviser might need to assess include:

- What structures best fit the task? Are structures needed for a wholeof-government approach or something less cross-cutting? Is there to be an interdepartmental committee or a taskforce or some other arrangement?

- What policy stages are to be followed and in what order? Is there to be formal consultation or informal consultations? Are these to be ongoing or episodic? If a formal process, are meetings to be made public or just bilateral? Is the evaluation to be internal or external?

- If the policy issue has a longer-term objective, can it be achieved in one budget measure or should the policy objective be phased in over time?

- Should the policy issue from a line agency be shared first with central agencies and/or go before a minister or ministers for guidance?

- Who should be involved: Which agencies, public servants, ministerial advisers and non-government players? When in the process should they be involved? What accountabilities should they have?

These are examples of how a policy official can exercise agency as described by Mackie (this volume, Chapter 9). A key consideration is how policy advisers interact with ministerial staff, as described below.

\section{Dealing with ministers and their staff}

A minister (or group of ministers) is pivotal in the policy process; therefore, 'managing up' effectively to a minister can take considerable skill, including, critically, learning on-the-job about their relevant characteristics. Are they extravert or introvert? Do they think in pictures and need oral briefing or do they prefer reading words on a page? Are they highly intuitive or more analytical? Former minister Nicola Roxon provided some advice to public servants, including to be 'strategically smart and adapt advice' by framing it based on who you are talking to, and 'ascertain at the beginning if your minister is a talker or a reader when it comes to processing advice' (as cited in Donaldson 2018). 
The relationship of ministers and their staff with the public service has evolved over the decades (see Edwards 2002; Holland 2006; Maley 2000; Nethercote 2002). In the 1980s, the attitude of some senior public servants with whom I worked was that 'ministers come and go, but we remain'. At that time, ministers answered for the actions of officials (as well as their advisers). By the early 1990s, as a consequence of a series of deliberate changes to public service tenure, departmental structures and reward systems, the balance of power had switched to the political executive. This put public servants in the frontline, defending ministers and their staff (Nethercote 2002). Today there are more ministerial advisers than ever before (although not necessarily with the same level of policy expertise as in the past).

A learning experience for me arose from a media article in 1996 that claimed that senior officials in the Department of the Prime Minister and Cabinet $(\mathrm{PM} \& \mathrm{C})$ regarded the advisers in the Prime Minister's Office (PMO) as 'amateurish'. Of course, this claim sparked fury from the PMO and also from the prime minister himself. The article came some months after an intensive effort by senior PM\&C officials to build up good relationships with the newly elected Prime Minister Howard and his staff (Edwards 2002). Such a setback can quickly destroy trust that might have taken months to build up. This illustrates how important it is to take care in building up and maintaining a respectful relationship with a minister's office, however time-consuming that may be. This is a precondition for being able to offer 'frank and fearless' advice.

\section{Placing value on networks and relationships}

The role of relationships and policy networks of players, at whatever stage of the policy process, should never be underrated in assisting policy development and affecting its outcomes (see Althaus, Bridgman \& Davis 2018, p. 229-30; Behm 2015, pp. 215-16; Edwards 2004, p. 6). Aside from a minister or ministers, key players could include elected officials, public servants, interest groups, non-government organisations from the community, business and elsewhere, researchers, consultants and think tanks, and also the media. People who you know or have known in various capacities, both inside and outside government, can often turn out to be valuable later on in assisting a policy agenda move on. 
Informal networks of key players were especially important in putting long-term unemployment on the agenda in the early 1990s, in which key ministerial advisers, bureaucrats and academics were in constant contact through informal processes (see examples in Edwards 2001, pp. 145-6, 188; Edwards \& Stewart 2017, p. 341). They were also beneficial in the case of child support, in which informal contacts with the legal profession, social welfare and women's groups assisted in minimising adverse comments on the proposed reform.

Collaborating or 'managing across' with people from other agencies inside government to the outside and vice versa is needed if any complex policy issue is to move towards a resolution. Importantly, it needs to be a strategic process about why collaboration is needed, when it should occur, with whom and how. It may mean up-front informal bilateral discussions followed by broader collaborations depending on the sensitivity and complexity of the issue.

Today policy advisers' networks have widened as the sources of policy advice to ministers have broadened. Although policy advising remains a major function of public servants, increasingly they compete with private and other non-government advisers.

\section{Managing the researcher-policy practitioner interface}

Not all research is, or should be, attempting to inform policy. There currently exists a real conflict here for academics who, while wanting to have policy influence, face incentive structures in universities that emphasise publications in what are rated as quality journals.

However, there is considerable evidence that, if research is to better inform policy, it is not the written word as much as dialogue, interaction (e.g. in round tables) and ongoing related mechanisms (and relationships) between policy practitioners and researchers that work best (see Australia and New Zealand School of Government [ANZSOG] 2007; Head \& Crowley 2015; Nutley, Walter \& Davies 2007). Moreover, that dialogue is helped if the issues discussed are of concern to the government of the day. Busy policy people will use trusted experts, but otherwise are not in the habit of reading what are often dense research papers. 
None of the major social policy exercises in which I was involved would likely have seen the light of day without the involvement of academic researchers at key stages in policy development. However, the success stories were of researchers going beyond their written words to interact and engage with policymakers and to convince them of the worth of their ideas. Hence the importance of dialogue and of building relationships and trust across the sectors.

In 2007, an ANZSOG project interviewed senior public servants and academics on both sides of the Tasman to find out what research they would most value. In the process the fragility of the academic-public servant relationship came to the fore, best illustrated by one humorous (if it were not so pointed) rhetorical question from a senior official: 'What is the difference between an academic and a terrorist? You can negotiate with a terrorist.' More positively, they identified the need for round tables with experts on issues of concern to them and also the use of knowledge brokers to assist in bridging the researcher-policy practitioner gap (ANZSOG 2007).

If policy influence is the goal, then, as unpalatable as it may seem to some, research cannot be a standalone activity; rather, it should be viewed, as policymaking is-more as part of a process. To be clear, for research to impact on policy, it needs to be part of the policy process and vice versa.

My case studies on developing policy indicate that policy ideas from academics can assist in moving a policy forward. For example, the idea of using the tax system to assess and collect child support came from an American researcher. But that is not to deny that the greatest value of academic policy research usually comes in assisting in identifying the problem and in analysis, if not also evaluation (Edwards 2010b, pp. 59-61).

\section{Being pragmatic and managing ambiguity}

A policy idea can at times assist ministers get out of a bind with a particular problem that has so far not been resolved, but it rarely translates into practice without significant modification. Second best or even third best solutions may need to be accepted. Hence, anyone involved in the policy process needs to be pragmatic about what can be achieved, including dealing with trade-offs and ambiguity_-from policy objectives to policy 
decisions. French (2012, p. 538), a former minister in the Canadian Government, refers to 'fast and frugal forms of rationality that sacrifice any pretence to optimisation'.

Trade-offs are the name of the game for policy and political players. They come in many forms, for example, between exercising strong leadership and dealing collaboratively within networks; facing political demands, including short time-spans while also facing a shortage of resources; being responsive to a minister's agenda while the public support for it might be lacking; and managing risk or fearing failure while also being innovative.

Relationships get tested when there is more than one person to whom you 'manage up'. As a ministerial consultant working out of a department, I was answerable to the secretary of the department as well as the minister. I faced the same uncertainty when working from PM\&C on youth allowance policy but reporting to a line minister who was assisting the prime minister on youth affairs.

A highly valued skill of a person who provides policy advice is good judgement. This is hard to define and is partly based on experience, but also in some ways it is innate. Good judgement relates to having clarity about the longer-term desired outcomes and being able to use both a strategic and tactical approach to get there, accepting trade-offs and being adaptable so as to take political sensitivities into account. An example would be involving those who are to be responsible for implementing a policy in the early stages of policy development: knowing when to take notice and when to challenge them on possible implementation hurdles (see e.g. Edwards 2001, pp. 84, 95).

There is a related need to be able to deal with ambiguity. A senior policy adviser will often leave a meeting with a minister or ministers without clarity around what was meant by what was said. How a policy adviser responds to that circumstance is obviously going to be critical. Good judgement is required on how to gain the needed clarification, including assessing whether the minister actually understood what was said at the briefing session or, rather, judged it best politically not to have that clarification. 


\section{Concluding observations}

Coming towards the end of my working life, most of which has been spent either assisting in the development of policy or commenting on policyrelated processes and issues, I remain of the view that a policy development framework can be invaluable in contributing to good policy processes being followed. However, even as a normative framework, it can be rather sterile, if not simplistic to follow, if used on its own. As indicated above, the organisational structures and processes within which policy analysis occurs is important. Also important is the combination of players for any policy exercise-ministers, their advisers, public servants, academics and other non-government players. Both academics wanting to be boundary players with the public sector and public servants wanting to be more outward focused need to engage in dialogue and interaction. Above all of this, of course, is the paramount importance of that least in control factor for policy advisers - the politics: it determines whether policy progresses from stage to stage and, if it does, at what pace.

Let me end on a most salutary reflection: regardless of hard you might try, any good policy outcome you may have had some input into can be eroded, if not reversed, sometime in the future. However, as this contribution has attempted to show, the more effort put into the process of developing policy, the more durable it is likely to be.

\section{References}

Althaus, C, Bridgman, P \& Davis, G 2018, The Australian policy handbook: A practical guide to the policy-making process, 6th edn, Allen \& Unwin, Crows Nest, NSW.

Australia and New Zealand School of Government (ANZSOG) 2007, 'Enhancing ANZSOG's contribution to better government: Future research directions', Research Reference Group, October.

Banks, G 2010, 'Successful reform: Past lessons, future challenges', Keynote address to the Annual Forecasting Conference of the Australian Business Economists, Sydney, 8 December.

Banks, G 2013, 'Good processes underpin strong innovative policy', Australian Financial Review, 22 March, p. 2. 
Banks, G 2014a, The governance of public policy: Lectures in honour of eminent Australians, ANZSOG, Carlton, Vic.

Banks, G 2014b, 'Return of the rent-seeking society [Stan Kelly Lecture, The Economic Society of Australia, Melbourne, August 2013]', in G Banks, The governance of public policy: Lectures in honour of eminent Australians, ANZSOG, Carlton, Vic.

Banks, G 2018, 'Whatever happened to "evidence based policy making"?' Alf Rattigan Lecture 2018, ANZSOG, Carlton, Vic.

Beauchamp, G 2016, 'The role of government in innovation', in Twelve speeches 2016: A year of speeches from public service leaders, Institute of Public Administration Australia, Barton, ACT.

Behm, A 2015, No, minister: So you want to be a chief of staff?, Melbourne University Press, Carlton, Vic.

Botterill, L \& Fenna, A 2019, Interrogating public policy theory: A political values perspective, Edward Elgar, Cheltenham, UK, doi.org/10.4337/ 9781784710088.

Bridgman, P \& Davis, G 2003, 'What use is a policy cycle? Plenty, if the aim is clear', Australian Journal of Public Administration, vol. 63, no. 2, pp. 98-102, doi.org/10.1046/j.1467-8500.2003.00342.x.

Bromwell, D 2017, The art and craft of policy advising: A practical guide, Springer International Publishing, Cham, Switzerland, doi.org/10.1007/978-3-31952494-8.

Burgess, V 2017, 'It has home-grown hindsight, but can the public change?' Mandarin, 4 October.

Cairney, P \& Kwiatkowski, R 2017, 'The politics of evidence-based policymaking: How can we maximize the use of evidence in policymaking?', Palgrave Communications Special Issue, Palgrave, New York, NY.

Colebatch, H 2006, Beyond the policy cycle: The policy process in Australia, Allen \& Unwin, Sydney, NSW.

Dennett, H 2017, 'Get ready for more disruption: Parkinson floats national citizen survey', Mandarin, 12 December.

Donaldson, D 2018, “'Urgent”: Former secretaries assess public service capability', Mandarin, 12 February.

Edwards, M 2001, Social policy, public policy: From problem to practice, Allen \& Unwin, Sydney, NSW. 
Edwards, M 2002, 'Ministerial advisers and the search for accountability', Canberra Bulletin of Public Administration, no. 105, September.

Edwards, M 2004, Social science research and public policy: Narrowing the divide, Occasional paper, Policy paper no. 2, Academy of the Social Sciences, Canberra, ACT.

Edwards, M 2010a, 'The policy-making process', in D Woodward, A Parkin \& J Summers (eds), Government, politics, power and policy in Australia, 9th edn, Pearson Australia, Frenchs Forest, NSW.

Edwards, M 2010b, 'Making research more relevant to policy: Evidence and suggestions', in G Bammer, A Michaux, A Sanson (eds), Bridging the 'knowdo' gap: Knowledge brokering to improve child well-being, ANU E Press, Canberra, ACT, doi.org/10.22459/BKDG.08.2010.04.

Edwards, M, Halligan, J, Horrigan, B \& Nicoll, G 2012, Public sector governance in Australia, ANU E Press, Canberra ACT, doi.org/10.22459/PSGA.07.2012.

Edwards, M, Head, B, Tiernan, A \& Walter, J 2017, 'Policy capacity decline: Trends, causes and remedies', paper presented to the Australian Political Studies Association Conference, Monash University, 25-27 September.

Edwards, M \& Stewart, M 2017, 'Pathways and processes: Toward a gender equality policy', in M Stewart (ed.) Tax, social policy and gender, ANU Press, Canberra ACT, doi.org/10.22459/TSPG.11.2017.11.

Everett, S 2003, 'The policy cycle: Democratic process or rational paradigm revisited?, Australian Journal of Public Administration, vol. 62, no. 2, pp. 65-70, doi.org/10.1111/1467-8497.00325.

French, R 2012, 'The professors on public life', The Political Quarterly, vol. 83, no. 3, pp. 532-40, doi.org/10.1111/j.1467-923X.2012.02320.x.

Head, B 2015, 'Toward more "evidence-informed" policy making?', Public Administration Review, vol. 76, no. 3, pp. 472-84, doi.org/10.1111/puar.12475.

Head, B \& Crowley, K (eds) 2015, Policy analysis in Australia, Policy Press, Bristol, UK, doi.org/10.1332/policypress/9781447310273.001.0001.

Holland, I 2006, 'Parliamentary committees as an arena for policy work', in $\mathrm{H}$ Colebatch (ed.), Beyond the policy cycle: The policy process in Australia, Allen \& Unwin, Sydney, NSW.

Keating, M 1996, 'Defining the policy advising function', in J Uhr \& K McKay (eds), Evaluating policy advice, Federalism Research Centre, ANU and Commonwealth Department of Finance, Canberra, ACT. 
Keating, M 2017, 'The Productivity Commission on more effective government. Part 2 of 2', John Menadue - Pearls and Irritations, 14 December, viewed 5 March 2020, johnmenadue.com/michael-keating-the-productivitycommission-on-more-effective-government-part-2-of-2/.

Kingdon, J 1995, Agendas, alternatives and public policies, Harper and Collins, New York, NY.

Maley, M 2000, 'Conceptualising advisers' policy work: The distinctive policy roles of ministerial advisers in the Keating government, 1991-96', Australian Journal of Political Science, vol. 35, no. 3, pp. 449-70, doi.org/ 10.1080/713649346.

Nethercote, JR 2002, 'What servants are for', Sydney Morning Herald Web Diary, 27 June.

Nutley, S, Walter, I \& Davies, H 2007, Using evidence: How research can inform public services, Policy Press, Bristol, UK, doi.org/10.2307/j.ctt9qgwt1.

Productivity Commission 2017, Shifting the dial: 5 year productivity review, Productivity Commission, Canberra, ACT.

Shergold, P 2015, Learning from failure: Why large government policy initiatives have gone so badly wrong in the past and how the chances of success in the future can be improved, APSC, Canberra, ACT.

Strangio, P, 't Hart, P \& Walter, J 2017, The pivot of power, Miegunyah Press, Carlton, Vic.

Wilenski, P 1986, Public power and public administration, Hale and Iremonger, Sydney, NSW. 
This text is taken from Learning Policy, Doing Policy: Interactions Between Public Policy Theory, Practice and Teaching, edited by Trish Mercer, Russell Ayres, Brian Head and John Wanna, published 2021 by ANU Press, The Australian National University, Canberra, Australia. 